\title{
Meningkatkan Aktivitas dan Hasil Belajar Siswa Melalui Model Kooperatif TTW Berbantuan Media Leaflet
}

\author{
Ida Farida ${ }^{1}$, Kurnia Ningsih ${ }^{2}$, Titin ${ }^{3}$ \\ ${ }^{1,2,3}$ Biology Education Study Program, University Tanjungpura. Prof. Dr. H. Hadari Nawawi Street, \\ Pontianak 78124, Indonesia \\ Coressponding Author. E-mail: \\ 1 iidafarida@gmail.com \\ 2 nia_untan@yahoo.com \\ 3titin@fkip.untan.ac.id
}

Received: 8 Januari 2020

Accepted: 28 Januari 2020 Online Published: 31 Januari 2020

\begin{abstract}
Abstrak
Penelitian ini bertujuan untuk meningkatkan aktivitas dan hasil belajar siswa melalui model kooperatif think talk. write berbantuan media leaflet pada materi perubahan lingkungan kelas X MIA 3 SMA Muhammadiyah 1 Pontianak. Metode penelitian yang digunakan adalah penelitian tindakan kelas yang dilakukan dalam dua siklus dengan dua kali pertemuan. Setiap siklusnya terdiri dari 4 tahapan yaitu: perencanaan, pelaksanaan, observasi, dan refleksi. Instrumen yang digunakan berupa lembar observasi aktivitas belajar siswa, lembar observasi proses pelaksanaan pembelajaran, dan tes hasil belajar. Hasil penelitian menunjukkan jumlah siswa dengan kategori aktif pada siklus I sebesar 60,61\% dan meningkat pada siklus II sebesar 75,76\%. Persentase ketuntasan hasil belajar siswa pada siklus I sebesar 75,76\% dan meningkat pada siklus II sebesar 87,88\%. Persentase proses pembelajaran siklus I sebesar $94.44 \%$ dengan kategori baik dan meningkat pada siklus II sebesar 100\% dengan kategori baik. Secara keseluruhan pembelajaran kooperatif think talk write berbantuan leaflet dapat meningkatkan aktivitas dan hasil belajar siswa pada materi perubahan lingkungan di kelas $\mathrm{X}$ MIA 3 SMA Muhammadiyah 1 Pontianak.
\end{abstract}

Kata Kunci: Aktivitas; Hasil belajar; think talk write berbantuan leaflet.

\begin{abstract}
This research was aimed to improve students' activities and learning outcomes through the 'think talk write' cooperative model using leaflet media in the material of environmental changes at Class X MIA of SMA Muhammadiyah 1 Pontianak. The method implemented in this research was classroom action research conducted in two cycles with two meetings. Each cycle comprised of four steps: planning, implementing, observation, and reflection. The instruments used in data collection were observation sheet of students' activity, an observation sheet of the learning process, and a test. The findings showed that in cycle I, $60.61 \%$ of students were categorized active and increased in cycle II by $75.76 \%$. The percentage of completeness of student learning outcomes in the cycle I was $75.76 \%$ and increased in cycle II by $87.88 \%$. The percentage of the learning process in the first cycle was $94.44 \%$ in the good category and increased in the second cycle by $100 \%$ in the good category. Based on the findings, it was concluded that the selected learning model improved students' activities and learning outcomes in the material of environmental changes at class X MIA 3 of SMA Mubammadiyah 1 Pontianak.
\end{abstract}

Keywords: Activities; Learning outcomes; Think talk, write assisted by leaflet.

How to cite this article :

Farida, I., Ningsih, K., \& Titin, T. (2020). Meningkatkan Aktivitas dan Hasil Belajar Siswa Melalui Model Kooperatif TTW Berbantuan Media Leaflet. IJIS Edu : Indonesian Journal of Integrated Science Education, 2(1), 7-18. doi:http://dx.doi.org/10.29300/ijisedu.v2i1.2714 


\section{PENDAHULUAN}

Kegiatan pembelajaran merupakan kegiatan paling utama dalam usaha peningkatan mutu pendidikan Indonesia. Kegiatan pembelajaran menghasilkan perubahan pada perilaku siswa. Hal ini senada dengan Undang-undang Sistem Pendidikan Nasional No. 20 tahun 2003 mengemukakan tujuan pendidikan nasional sebagai berikut: Pendidikan nasional bertujuan untuk mengembangkan potensi peserta didik agar menjadi manusia yang beriman, bertaqwa kepada Tuhan Yang Maha Esa, berakhlak mulia, sehat, berilmu, cakap , kreatif, mandiri, dan menjadi warga negara yang demokratis serta bertanggung jawab.

Menyadari pentingnya mutu pendidikan, dibutuhkan peranan guru dalam memilih strategi pembelajaran dan keterlibatan siswa secara optimal sehingga proses belajar mengajar lebih bermakna, sebagaimana pendapat Hamijoyo (dalam Huda, 2016) bahwa guru sebagai inovator berkat kemajuan ilmu pengetahuan dan teknologi, maka masyarakat senantiasa berubah dan berkembang dalam semua aspek. Perubahan dan perkembangan itu menuntut terjadinya inovasi pedidikan yang menimbulkan perubahan yang baru, berbeda dengan hal yang sebelumnya. Namun kebanyakan dalam praktek pendidikan, guru memegang peran yang dominan sehingga guru berfungsi sebagai sumber belajar dan pemegang otoritas tertinggi keilmuan (teacher centered). Pandangan semacam ini perlu diubah, guru hendaknya menerapkan variasi strategi pembelajaran dan menekankan agar peserta didik aktif dalam kegiatan pembelajaran. Agar dapat memaksimalkan peranannya guru harus merencanakan proses pembelajaran dengan pedoman yang dinamakan model pembelajaran.

Salah satu model pembelajaran yang dapat memaksimalkan keterlibatan siswa dalam proses pembelajaran adalah model pembelajaran kooperatif. Menurut Suprijono (2014) pembelajaran kooperatif adalah model pembelajaran yang dapat membuat siswa dapat bekerja sama sehingga adanya partisipasi aktif dari siswa. Guru sebagai fasilitator dan pembimbing yang akan mengarahkan setiap siswa menuju pengetahuan yang benar dan tepat.

Selain kemampuan merancang model pembelajaran, guru juga harus menguasai dan memahami media yang sesuai dengan tujuan mempermudah pemahaman siswa. Menurut
Asyhar (2015) "Media pembelajaran dapat dipahami sebagai segala sesuatu yang dapat menyampaikan atau menyalurkan pesan dari sumber secara terencana, sehingga terjadi lingkungan belajar yang kondusif dimana penerimanya dapat melakukan proses belajar secara efisien dan efektif'. Dapat disimpulkan bahwa media pembelajaran merupakan bagian tak terpisahkan dari kegiatan pembelajaran di sekolah. Pemanfaatan media pembelajaran juga merupakan upaya kreatif dan sistematis untuk menciptakan pengalaman yang dapat membantu proses belajar siswa. Hal ini dikarenakan media berperan sebagai alat perangsang belajar dan dapat menumbuhkan motivasi belajar sehingga murid tidak mudah bosan dalam mengikuti proses belajar mengajar. Media juga sangat diperlukan untuk mata pelajaran eksakta seperti biologi.

Berdasarkan hasil wawancara pada Agustus 2018, bahwa metode yang digunakan dalam proses pembelajaran materi perubahan lingkungan di kelas X SMA Muhammadiyah 1 Pontianak berupa metode ceramah dan tanya jawab disertai observasi di lingkungan sekitar sekolah untuk mengamati pencemaran lingkungan yang terjadi. Namun berdasarkan pengamatan peneliti di lingkungan sekitar sekolah kurang memadai untuk menunjang pencapaian tujuan pembelajaran pada materi tersebut, karena salah satu tujuan pembelajaran yang diharapkan dapat dicapai siswa adalah dapat mengidentifikasi jenis-jenis pencemaran lingkungan, seperti pencemaran tanah, air, udara, serta suara. Sedangkan jenis pencemaran yang terdapat di lingkungan sekolah hanya pencemaran air. Selain itu menurut Hisyam (2008) penggunaan metode ceramah berdampak kurang baik terhadap aktivitas siswa, karena menjadikan siswa cenderung bersifat pasif dikarenakan informasi yang bersifat satu arah.

Berdasarkan observasi Agustus 2018 di kelas X MIA 3 tahun ajaran 2018/2019, data hasil observasi guru saat mengajar pada materi ruang lingkup biologi (submateri cabang-cabang ilmu biologi). Aktivitas belajar siswa tergolong kurang, metode yang digunakan guru adalah metode ceramah dan tanya jawab sehingga proses pembelajaran masih didominasi oleh guru yang menyebabkan rendahnya aktivitas siswa. Adapun indikator aktivitas yang diamati adalah siswa bertanya kepada guru, siswa menjawab pertanyaan guru, siswa mencatat materi yang disampaikan guru, siswa memperhatikan guru, 
dan siswa membaca buku pelajaran. Rata-rata persentase aktivitas belajar siswa dari total 5 indikator adalah 37,04\%, data hasil aktivitas belajar siswa tersebut diperoleh ketika guru biologi mengajar dan peneliti sebagai observer. Data hasil aktivitas belajar tersebut tidak jauh berbeda dengan data yang diperoleh peneliti dengan indikator aktivitas yang sama ketika mengajar materi keanekaragaman hayati pada tanggal 18 September 2018 dengan menggunakan metode ceramah dan tanya jawab. Rata-rata persentase aktivitas belajar siswa adalah 31,74\%.

Data aktivitas di atas tergolong rendah untuk menunjang hasil belajar yang tinggi. Karena keaktifan siswa merupakan salah satu faktor yang mempengaruhi hasil belajar. Sebagaimana yang disampaikan oleh Sudjana (2010) bahwa "Hasil belajar merupakan kemampuan-kemampuan yang dimiliki siswa setelah menerima pengalaman belajarnya. Belajar yang berhasil harus melalui berbagai macam aktivitas, baik aktivitas fisik maupun psikis agar dapat memunculkan perubahan tingkah laku yang mengarah pada hasil belajar". Oleh karena rendahnya aktivitas belajar diatas menyebabkan hasil belajar yang rendah.

Berdasarkan data hasil ulangan harian mata pelajaran biologi kelas X MIA SMA Muhammadiyah 1 Pontianak semester genap tahun ajaran 2017/2018. Nilai rata-rata paling rendah diantara kelas X MIA 1, X MIA 2, dan X MIA 3 pada mata pelajaran kelas X MIA 3 yaitu sebesar 76,7. Sementara kelas X MIA 1 memiliki rata-rata sebesar 78,6, dan kelas X MIA 2 sebesar 79,5. Nilai tersebut tidak jauh berbeda dengan nilai ulangan harian siswa kelas X MIA SMA Muhammadiyah 1 Pontianak semester ganjil tahun ajaran 2018/2019, yang mana kelas X MIA 3 juga memiliki nilai rata-rata paling rendah diantara kelas X MIA 1 dan X MIA 2. Nilai ratarata X MIA 3 sebesar 78, sedangkan X MIA 1 sebesar 78,6 dan kelas X MIA 2 sebesar 79,5.

Data di atas menjadi alasan peneliti memilih kelas X MIA 3 sebagai subjek penelitian tindakan kelas. Selain itu, peneliti juga memilih materi perubahan lingkungan untuk dilakukan penelitian karena berdasarkan data hasil ulangan harian di kelas X MIA 3, materi perubahan lingkungan adalah materi dengan rata-rata nilai dan persentase ketuntasan yang rendah dibandingkan materi yang lain dan materi tersebut juga tidak mencapai kriteria ketuntasan minimal (KKM) yaitu 75 .
Melihat realita di lapangan terkait akivitas belajar siswa yang rendah dan banyaknya jumlah siswa yang belum tuntas hasil belajar sesuai dengan kriteria ketunasan minimal,maka diperlukan langkah-langkah yang kreatif dan inovatif dalam pembelajaran untuk menjawab persoalan tersebut. Berdasarkan konteks masalah tersebut diperlukan sebuah model pembelajaran yang mendorong aktivitas siswa sehingga dapat menunjang hasil pembelajarannya. Model pembelajaran yang dipilih adalah model pembelajaran kooperatif TTW.

Model pembelajaran kooperatif TTW. dikembangkan oleh Huinker dan Laughlin yang dibangun melalui berpikir, berbicara dan menulis. think talk write secara harfiah berarti "berpikir", "berbicara", dan "menulis". Menurut Kamus Besar Bahasa Indonesia, berpikir adalah menggunakan akal budi untuk mempertimbangkan dan memutuskan sesuatu; menimbang-nimbang dalam ingatan, berbicara adalah melahirkan pendapat dengan perkataan, dan menulis adalah melahirkan pikiran atau perasaan dengan tulisan. Menurut Suyatno (2009) model pembelajaran kooperatif TTW adalah pembelajaran yang dimulai dengan berfikir dengan bahan bacaan (menyimak, mengkritisi, dan alternatif solusi), hasil bacaannya dikomunikasikan dengan presentasi, diskusi, dan kemudian membuat laporan hasil presentasi. Selain itu menurut Sanjaya (2014) pembelajaran kooperatif adalah pembelajaran yang melatih siswa untuk terlibat aktif dalam proses pembelajaran.

Agar dapat menunjang keberhasilannya dan untuk mempermudah melaksanakan model pembelajaran diperlukan media pembelajaran. Menurut Arsyad (2015) media pembelajaran adalah guru, buku, teks, dan lingkungan sekolah yang dapat membantu siswa memperoleh pengetahuan. Berdasarkan hasil wawancara pada Agustus 2018, media pembelajaran yang digunakan guru untuk mengajar materi perubahan lingkungan adalah media realia. Media realia adalah media pembelajaran yang memanfaatkan benda nyata sebagai bahan atau sumber belajar, dalam hal ini guru menjadikan lingkungan di sekitar sekolah untuk dijadikan media. Tujuan guru menggunakan media realia adalah agar siswa dapat mengamati jenis pencemaran di lingkungan sekitar sekolah. Namun berdasarkan pengamatan peneliti jenis pencemaran yang terdapat di lingkungan sekolah hanya pencemaran air, sedangkan berdasarkan 
tujuan pembelajaran terdapat 4 jenis pencemaran, yaitu pencemaran air, pencemaran udara, pencemaran tanah, dan suara.

Ditinjau dari permasalahan tersebut diperlukan suatu media pembelajaran yang dapat menyajikan jenis pencemaran secara lengkap. Media pembelajaran yang dimaksud adalah media leaflet. Menurut Murni (2010) "Leaflet merupakan bahan cetak tertulis berupa lembaran yang dilipat tapi tidak dimatikan/dijahit". Menurut Setyono (2005) media leaflet dapat menyajikan materi secara padat dan ringkas, serta menarik perhatian siswa.

Beberapa penelitian sebelumnya menyatakan bahwa model pembelajaran kooperatif TTW dapat meningkatkan aktivitas dan hasil belajar siswa. Diantaranya penelitian yang dilakukan oleh Sudarmiyati (2016) di SMPN 3 Batanghari pada mata pelajaran IPA, ia menyatakan bahwa hasil belajar siswa meningkat sebesar 36,67\%. Masitoh (2017) melakukan penelitian di SMPN 1 Kedungwuni pada mata pelajaran IPA konsep sistem gerak pada manusia, menyatakan bahwa hasil yang dilakukan menunjukkan peningkatan aktivitas sebesar $12,5 \%$ dari siklus 1 ke siklus 2. Model pembelajaran TTW yang dilakukan dengan baik dan benar mampu menumbuhkan antusias dan kegembiraan siswa selama proses pembelajaran IPA sehingga keaktifan mereka meningkat dan pada akhirnya hasil belajar IPA mereka juga meningkat.

Selain model pembelajaran TTW (think talk write), beberapa penelitian juga menunjukkan bahwa media leaflet dapat membantu meningkatkan aktivitas dan hasil belajar. Diantaranya penelitian yang dilakukan oleh Hermawan (2013) pada mata pelajaran IPA di kelas VII MTs Al-Furqon Rawi. Persentase ratarata aktivitas siswa pada setiap siklus mengalami peningkatan sebesar 8,8\%. Selain itu, Ameliawati (2013) melakukan penelitian pengaruh penggunaan media pembelajaran leaflet terhadap aktivitas dan hasil belajar siswa pada materi pokok sistem pencernaan makanan di kelas VIII SMP Muhammadiyah 1 Gadingrejo Kabupaten Pringsewu Tahun Pelajaran 2013/2014. Hasil penelitiannya menunjukkan bahwa aktivitas belajar siswa meningkat dengan rata-rata 78,23. Hasil belajar mengalami peningkatan dengan ratarata nilai pretest $(36,94)$, postest $(72,22)$, dan $\mathrm{N}$ gain $(56,50)$.
Berdasarkan uraian di atas perlu dilakukan Penelitian Tindakan Kelas (PTK) untuk meningkatkan aktivitas belajar dan hasil belajar siswa. Maka dari itu penulis melakukan penelitian yang berjudul, meningkatkan aktivitas dan hasil belajar siswa dengan menggunakan model kooperatif tipe TTW berbantuan media leaflet pada materi perubahan lingkungan di kelas $\mathrm{X}$ MIA 3 SMA Muhammadiyah 1 Pontianak.

\section{METODE}

Bentuk penelitian ini adalah penelitian tindakan kelas, menurut Kusuma dan Dwitagama (2010), "Penelitian Tindakan Kelas (PTK) adalah penelitian yang dilakukan oleh guru di kelasnya sendiri dengan cara (1) merencanakan, (2) melaksanakan, dan (3) merefleksikan tindakan secara kolaboratif dan partisipasif."

Penelitian ini termasuk dalam penelitian tindakan kelas kolaboratif. Menurut Oja (dalam Mahmud, 2011), penelitian tindakan kelas dengan bentuk kolaboratif melibatkan beberapa pihak baik guru, kepala sekolah, maupun dosen secara serentak dengan tujuan meningkatkan praktik pembelajaran, menyumbang perkembangan teori, dan peningkatan karier guru

Penelitian ini dilaksanakan oleh suatu tim terdiri dari peneliti dan guru Biologi yang merupakan guru pamong pada Program Pengalaman Lapangan (PPL) di SMA Muhammadiyah 1 Pontianak. Hubungan guru dan peneliti bersifat kemitraan sehingga dapat secara bersama-sama untuk memecahkan masalah rendahnya aktivitas dan hasil belajar siswa materi perubahan lingkungan kelas X MIA 3 SMA Muhammadiyah 1 Pontianak. Guru Biologi tersebut juga bertindak sebagai observer untuk mengamati proses pembelajaran kooperatif TTW berbantuan leaflet. Selain itu, terdapat 3 observer lainnya yang merupakan rekan peneliti untuk mengamati aktivitas belajar siswa di kelas.

Subjek dalam penelitian tindakan kelas ini adalah siswa kelas $\mathrm{X}$ MIA 3 SMA Muhammadiyah 1 Pontinak tahun pelajaran 2018/2019, dengan jumlah siswa sebanyak 34 orang yang terdiri dari 15 siswa laki-laki dan 19 siswa perempuan.

Tahap persiapan dilakukan oleh guru untuk menyiapkan perangkat pembelajaran seperti silabus, RPP, LKPD, dan lembar validasi instrument dan media. Selain itu peneliti menyiapkan instrumen penelitian seperti lembar observasi dan tes hasil belajar. 
Penelitian ini dilakukan dengan dua siklus yaitu siklus I dan siklus II. Setiap siklus terdiri atas satu kali pertemuan (2JP). Adapun prosedur tindakan dimulai dari perencanaan, tindakan, observasi dan refleksi. Kekurangan yang ada pada siklus I nantinya akan diperbaiki pada siklus II (Arikunto, 2013).

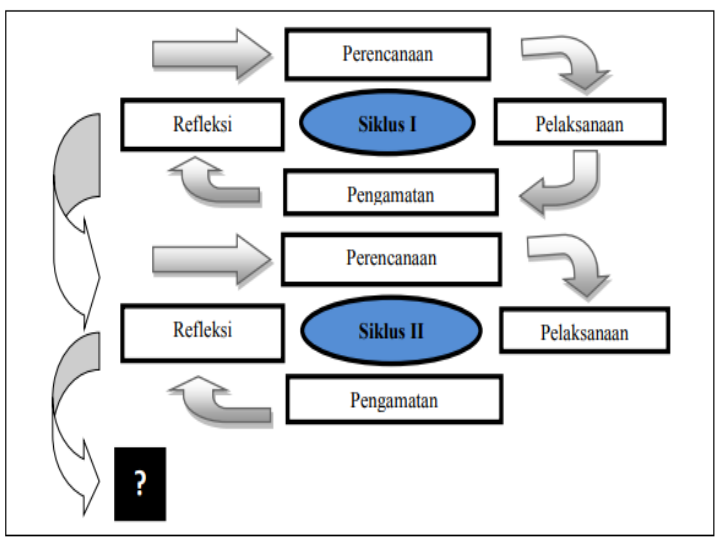

Gambar 1. Prosedur penelitian tindakan kelas (Uno, dkk. 2014)

Intrumen penelitian yang digunakan yaitu tes hasil belajar dan lembar observasi. Tes hasil belajar digunakan untuk mengukur keberhasilan peserta didik dalam proses belajar pembelajaran, tes hasil belajar yang disusun adalah bentuk soal tes pilihan ganda. Lembar observasi terdiri atas dua jenis, yang pertama lembar observasi aktivitas untuk mengukur aktivitas belajar siswa dan yang kedua adalah lembar observasi proses untuk mengukur kesesuaian antara perencanaan dan pelaksanaan tindakan.

Teknik pengumpulan data yang digunakan dalam penelitian ini yaitu observasi untuk mengukur aktivitas siswa dan proses pembelajaran, pengukuran yang dimaksud adalah tes hasil belajar untuk mengukur hasil belajar siswa, wawancara untuk memperoleh informasi terkait proses pembelajaran sebelumnya, dan dokumentasi digunakan untuk memperoleh fotofoto saat tindakan dan data belajar siswa.

Indikator keberhasilan dalam penelitian ini untuk menentukan atau mengukur keberhasilan tindakan yang dilakukan pada penelitian ini.Tindakan yang dianggap berhasil apabila sekurang-kurangnya siswa yang tergolong dalam kategori aktif sebanyak $65 \%$ pada siklus I dan $75 \%$ pada siklus II. Sekurang-kurangnya siswa yang tergolong dalam kategori tuntas sebesar $75 \%$ siswa pada siklus 1 dan $85 \%$ pada siklus II. Sekurang-kurangnya proses pembelajaran dapat terlaksana sebesar $85 \%$ pada siklus 1 dan $90 \%$ pada siklus II.

\section{HASIL DAN PEMBAHASAN}

Hasil

Aktivitas Belajar Siswa

Aktivitas belajar secara klasikal meningkat sebesar $15,15 \%$, persentase jumlah siswa yang aktif pada siklus I sebesar $60,61 \%$ dan meningkat pada siklus II sebesar $75,76 \%$. Adapun persentase keterlaksanaan masing-masing indikator sebagai berikut.

Tabel 1. Persentase Aktivitas Siswa Tiap Indikator

\begin{tabular}{lcc}
\hline \multirow{2}{*}{ Aktivitas } & \multicolumn{2}{c}{ Persentase (\%) } \\
\cline { 2 - 3 } & Siklus I & Siklus II \\
\hline Membaca LKPD & 100 & 100 \\
\hline $\begin{array}{l}\text { Membaca } \\
\text { informasi pada } \\
\text { leaflet }\end{array}$ & 100 & 100 \\
\hline $\begin{array}{l}\text { Menjawab } \\
\text { pertanyaan }\end{array}$ & 54,55 & 63,64 \\
\hline $\begin{array}{l}\text { Mengajukan } \\
\text { pertanyaan }\end{array}$ & 39,39 & 63,64 \\
\hline $\begin{array}{l}\text { Berdiskusi dengan } \\
\text { teman kelompok }\end{array}$ & 100 & 100 \\
\hline $\begin{array}{l}\text { Mendengarkan } \\
\text { teman presentasi }\end{array}$ & 78,79 & 84,85 \\
\hline $\begin{array}{l}\text { Mendengarkan } \\
\text { guru menjelaskan }\end{array}$ & 100 & 100 \\
\hline $\begin{array}{l}\text { Menulis hasil } \\
\text { diskusi }\end{array}$ & 100 & 100 \\
\hline $\begin{array}{l}\text { Memberikan } \\
\text { saran/tanggapan }\end{array}$ & 15,15 & 30,30 \\
\hline
\end{tabular}

\section{Hasil Belajar Siswa}

Persentase ketuntasan hasil belajar siswa materi perubahan lingkungan dengan pembelajaran kooperatif TTW berbantuan leaflet siklus I sebesar $75,76 \%$ dan meningkat pada siklus II sebesar $87,88 \%$. Secara rinci dapat dilihat pada Gambar 2.Hasil penelitian disajikan dalam bentuk grafik, tabel, atau deskriptif. Analisis dan interpretasi hasil ini diperlukan sebelum dibahas.

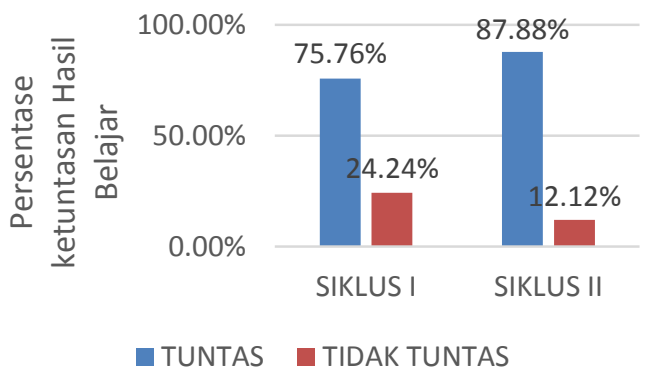

Gambar 2. Persentase Ketuntasan Hasil Belajar 


\section{Proses Pembelajaran Kooperatif TTW berbantuan leaflet}

Proses pembelajaran kooperatif TTW berbantuan leaflet dapat dilihat pada Gambar 3.

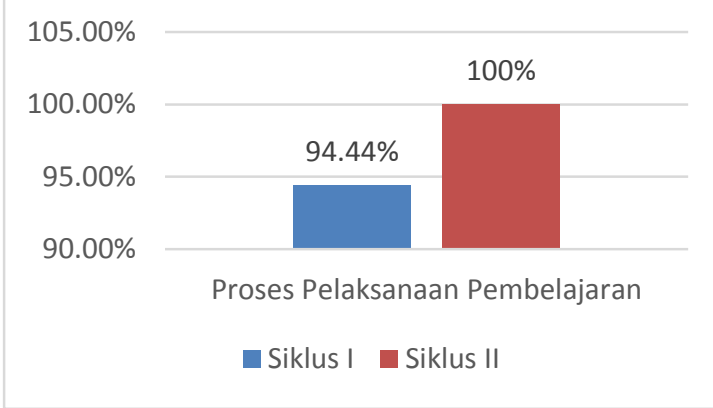

Gambar 3. Persentase Proses Pembelajaran Kooperatif TTW berbantuan leaflet

\section{Pembahasan}

\section{Peningkatan Aktivitas Belajar Siswa}

Berdasarkan Tabel 1, peningkatan aktivitas belajar masing-masing indikator sebagai berikut.

\section{Membaca LKPD}

Membaca LKPD merupakan salah satu aktivitas yang diamati pada penelitian ini. Guru membagi siswa menjadi 6 kelompok secara heterogen, kemudian masing-masing kelompok diberikan LKPD. Semua siswa diharapkan membaca kegiatan pada LKPD sebagai bahan untuk berdiskusi dengan teman kelompok. Pada siklus I dan siklus II semua siswa melakukan aktivitas membaca LKPD yang artinya persentase untuk aktivitas ini sebesar 100\% pada siklus I dan II.

2. Membaca informasi pada leaflet

Setelah membaca LKPD siswa diharapkan membaca media leaflet yang berisi materi pembelajaran. Media leaflet bertujuan untuk membantu siswa dalam mengerjakan LKPD. Setiap kelompok diberikan 2 set leaflet (satu set terdiri dari 3 leaflet), artinya setiap siswa memegang satu leaflet untuk dibaca. Pada siklus I dan siklus II semua siswa melakukan aktivitas membaca informasi pada leaflet yang artinya persentase untuk aktivitas ini sebesar $100 \%$ pada siklus I dan siklus II.

Salah satu penyebab meningkatnya minat membaca adalah dikarenakan media leaflet yang digunakan memiliki warna dan gambar yang menarik. Sebagaimana pendapat Setyono (2005) media leaflet dapat menyajikan materi secara padat dan ringkas, serta menarik perhatian siswa.
3. Menjawab pertanyaan (guru/teman)

Selama proses pembelajaran berlansung guru mengajukan beberapa pertanyaan kepada siswa, dan pada saat presentasi siswa juga berkesempatan menjawab pertanyaan dari siswa lain. Namun pada siklus I siswa yang menjawab pertanyaan cenderung siswa yang sama. Sehingga persentase jumlah siswa yang menjawab pertanyaan hanya sebesar $54,55 \%$. Kemudian pada siklus II guru membuat aturan bahwa setiap siswa hanya boleh menjawab satu pertanyaan sehingga persentase aktivitas menjawab pertanyaan meningkat menjadi $63,64 \%$. Selain untuk meningkatkan jumlah persentase siswa yang aktif upaya ini juga efektif untuk meningkatkan kerja sama siswa antar kelompok karena jika di dalam kelompok terdapat siswa yang tidak dapat menjawab pertanyaan maka akan dibantu oleh teman kelompoknya yang bisa. Upaya di atas juga digunakan oleh guru untuk membantu meningkatkan aktivitas mengajukan pertanyaan (kepada guru/teman) serta memberikan saran/tanggapan.

Upaya lain yang digunakan oleh guru untuk meningkatkan aktivitas menjawab pertanyaan adalah dengan tidak lansung memberikan jawaban atas pertanyaan yang diberikan oleh siswa terhadap guru. Sebelum menjawab pertanyaan tersebut guru mempersilahkan siswa yang belum melakukan aktivitas menjawab pertanyaan untuk memberikan jawaban yang sesuai dengan pertanyaan temannya.

Meningkatnya aktivitas menjawab pertanyaan sejalan dengan penelitian yang dilakukan oleh Sudarmiyati (2016) yang menggunakan model TTW, ia menyatakan bahwa aktivitas siswa menjawab pertanyaan meningkat sebesar $13,33 \%$ pada siklus II.

4. Mengajukan pertanyaan (kepada guru/teman)

Selama proses pembelajaran siswa dapat mengajukan pertanyaan terkait materi yang dipelajari kepada guru, kemudian mengajukan pertanyaan kepada teman saat berdiskusi. Persentase jumlah siswa yang bertanya pada siklus I sebesar 39,39\% dan meningkat pada siklus II menjadi 63,64\%. Peningkatan ini adalah hasil dari upaya yang dilakukan oleh guru seperti pada aktivitas menjawab pertanyaan (guru/teman). 
Hasil diatas didukung oleh penelitian yang dilakukan oleh Sudarmiyati (2016) yang menggunakan model kooperatif TTW, aktivitas bertanya meningkat sebesar $13,75 \%$.

5. Berdiksusi dengan teman kelompok.

Setelah memperoleh informasi pada leaflet, masing-masing anggota kelompok berdiskusi untuk memperoleh solusi yang tepat untuk memberikan jawaban pada kegiatan di LKPD. Semua anggota kelompok terlihat antusias berdiskusi karena masingmasing mereka telah membaca leaflet yang dibagikan. Sehingga jumlah persentase siswa yang melakukan aktivitas berdiksusi dengan teman kelompok sebesar 100\% pada siklus I dan siklus II.

Hasil penelitian ini didukung oleh Sudarmiyati (2016), yang mana aktivitas berdiskusi pada penelitiannya meningkat sebesar 13,33\% menggunakan model kooperatif TTW.

6. Mendengarkan teman presentasi

Mendengarkan teman presentasi adalah salah satu indikator aktivitas siswa yang diamati, masing-masing siswa wajib mendengarkan jalannya diskusi saat presentasi agar dapat terlibat aktif dalam mengajukan/menjawab pertanyaan dan memberikan saran/tanggapan serta agar siswa lebih memahami materi terkait. Adapun persentase jumlah siswa yang mendengarkan teman presentasi pada siklus I sebesar $78,79 \%$.

Terdapat 7 siswa yang tidak memperhatikan teman presentasi dikarenakan letak tempat duduk kelompok yang berada di pojokan kelas sehingga tak terjangkau oleh guru seperti kelompok VI dan III, sehingga guru kesulitan untuk mengontrol aktivitas siswa pada kelompok tersebut. Upaya yang dilakukan oleh guru pada siklus II adalah dengan meminta siswa untuk mengatur tata letak duduk masingmasing kelompok dengan baik agar guru tidak kesulitan mendatangi dan mengawasi kelompok tersebut. Persentase jumlah siswa yang mendengarkan teman presentasi meningkat menjadi $84,85 \%$. Peningkatan ini juga sejalan dengan penelitian Sudarmiyati (2016) menggunakan model kooperatif TTW meningkat sebesar $11,66 \%$ pada siklus II.

7. Mendengarkan guru menjelaskan

Ketika guru menyampaikan penjelasan materi yang terkait maka siswa wajib mendengarkannya. Pada siklus I dan siklus II semua siswa mendengarkan ketika guru menjelaskan materi pembelajaran. Penelitian yang dilakukan oleh Sudarmiyati (2016) juga mengalami peningkatan pada indikator mendengarkan guru menjelaskan yaitu sebesar $10,01 \%$.

8. Menulis hasil diskusi

Setelah melakukan diskusi terkait kegiatan pada LKPD setiap kelompok wajib menuliskan hasil diskusi bersama teman kelompoknya di LKPD pada bagian yang telah disediakan. Kemudian setiap siswa wajib menuliskan hasil diskusi berupa kesimpulan terkait materi yang dipelajari pada lembar yang telah disediakan oleh guru. Pada siklus I dan siklus II semua siswa menulis hasil diskusi tersebut sehingga persentase jumlah siswa yang melakukan aktivitas tersebut pada siklus I dan II sebesar $100 \%$.

Hasil tersebut didukung oleh penelitian yang dilakukan oleh Ryanti (2016) yang menggunakan model kooperatif TTW, aktivitas menulis meningkat sebesar 16,2\% pada siklus II.

9. Memberikan saran/tanggapan

Memberikan saran/tanggapan merupakan aktivitas dengan persentase paling rendah diantara aktivitas yang lain yaitu hanya sebesar $15,15 \%$ pada siklus I. Upaya yang dilakukan guru untuk meningkatkan aktivitas ini sama seperti aktivitas mengajukan pertanyaan (kepada guru/teman) dan menjawab pertanyaan (guru/teman), sehingga pada siklus II meningkat menjadi 30,30\%. Persentase tersebut masih jauh dibawah aktivitas belajar yang lain, rendahnya persentase aktivitas ini dikarenakan keberanian siswa untuk memberikan tanggapan/saran masih tergolong rendah dan juga kurangnya kesempatan yang diberikan guru karena keterbatasan waktu.

Walaupun persentase masing-masing indikator meningkat pada siklus II, namun berdasarkan hasil pengamatan terdapat 8 orang siswa yang mengalami penurunan aktivitas diantaranya. Secara umum penurunan tersebut adalah karena ketidakmampuan guru memonitoring partisipasi siswa, namun berdasarkan analisis peneliti ada dua penyebab penurunan aktivitas belajar siswa, diantaranya: 
1. Penyebab pertama adalah adanya upaya pembagian aktivitas yang dilakukan guru pada aktivitas menjawab pertanyaan (guru/teman), mengajukan pertanyaan (kepada guru/teman) dan memberikan saran/tanggapan.

2. Penyebab yang kedua ada pada kelemahan model kooperatif TTW yaitu ketika siswa bekerja dalam kelompok mudah kehilangan kemampuan dan kepercayaan terlebih jika didominasi oleh siswa yang mampu.

\section{Peningkatan Hasil Belajar}

Melalui Gambar 2 dapat diperhatikan bahwa persentase ketuntasan hasil belajar siswa dari siklus I ke siklus II meningkat sebanyak $12,12 \%$. Hasil tersebut telah mencapai indikator keberhasilan yang ditentukan. Meningkatnya hasil belajar menggunakan model kooperatif TTW berbantuan leaflet pada penelitian ini sesuai dengan penelitian yang dilakukan oleh Sibuea (2017). Ia berhasil meningkatkan hasil belajar siswa dengan menggunakan model kooperatif TTW. Selain itu Septiani, Tri Jalmo dkk (2014) menggunakan leaflet untuk meningkatkan hasil belajar siswa.

Meningkatnya hasil belajar siswa pada siklus II disebabkan oleh meningkatnya aktivitas belajar siswa. Sebagaimana yang disampaikan oleh Sudjana (2010) bahwa "Hasil belajar merupakan kemampuan-kemampuan yang dimiliki siswa setelah menerima pengalaman belajarnya. Belajar yang berhasil harus melalui berbagai macam aktivitas, baik aktivitas fisik maupun psikis agar dapat memunculkan perubahan tingkah laku yang mengarah pada hasil belajar". Pernyataan tersebut diperkuat dengan hasil penelitian Nuraini dkk (2018) yang menyatakan bahwa besarnya pengaruh aktivitas belajar siswa terhadap hasil belajar siswa di SMA 5 Pontianak dengan nilai koefesien determinasi sebesar 45,1\%.

Meskipun secara keseluruhan hasil belajar mengalami peningkatan, namun terdapat 7 siswa yang mengalami penurunan. Berdasarkan analisis peneliti terdapat 3 penyebab penurunan hasil belajar diantaranya:

1. Terjadinya penurunan aktivitas belajar siswa, sebagaimana dijelaskan di atas bahwa aktivitas belajar mempengaruhi hasil belajar siswa.

2. Rendahnya aktivitas belajar, yakni siswa yang tidak mengalami penurunan aktivitas (tetap) dari siklus I ke siklus II namun mengalami penurunan hasil belajar. Hal ini dikarenakan aktivitas belajar yang dilakukan tidak mampu menunjang untuk mendapatkan hasil belajar yang baik.

3. Kurangnya kemampuan pemahaman siswa terhadap materi pada siklus II, yakni siswa yang mengalami peningkatan aktivitas belajar namun hasil hasil belajar yang diperoleh menurun.

\section{Proses Pembelajaran Koopratif TTW berbantuan leaflet \\ Siklus I}

1. Perencanaan

Perencanaan merupakan tahapan awal dalam penelitian tindakan kelas. Pada tahap ini segala keperluan yang dibutuhkan dalam penelitian direncanakan dan dipersiapkan dengan baik. Guru menyiapkan segala bentuk perangkat dan instrument penelitian.

2. Pelaksanaan

Pertemuan pada siklus I dilaksanakan sesuai rencana pelaksanaan pembelajaran dengan alokasi waktu 2 x 45 menit. Tujuan pembelajaran pada siklus ini yaitu melalui kegiatan pembelajaran dengan model pembelajaran kooperatif TTW berbantuan leaflet peserta didik dapat menganalisis jenisjenis pencemaran, menganalisis penyebab pencemaran lingkungan, menganalisis dampak pencemaran lingkungan, dan mengaplikasikan upaya penanggulangan pencemaran.

Pelaksanaan tindakan pada siklus I dilakukan berdasarkan tahapan kegiatan dan langkah-langkah pembelajaran model kooperatif TTW modifikasi dari Maftuh dan Nurmani (dalam Hamdayana, 2015) yang terdapat di RPP sebagai berikut.

a. Menyampaikan tujuan dan mempersiapkan peserta didik.

b. Menyajikan informasi.

c. Mengelompokkan peserta didik.

d. Membantu kerja kelompok dan belajar.

1) Peserta didik mengidentifikasi masalah pada LKPD (think).

2) Peserta didik berdiskusi/bertukar pendapat untuk mengerjakan LKPD (talk).

3) Peserta didik menulis setiap poin dari hasil diskusi dan menulis kesimpulan secara utuh dari hasil diskusi (write).

e. Mengevaluasi.

f. Memberikan penghargaan.

3. Observasi 
Observasi adalah kegiatan untuk mengamati proses pembelajaran dan aktivitas pembelajaran. Proses pembelajaran terlaksana 94,44\%, guru tidak melakukan 1 langkah pembelajaran yaitu memberikan penghargaan kepada kelompok terbaik. Aktivitas belajar klasikal sebesar 60,61\% yang artinya persentase jumlah siswa yang aktif pada siklus 1 belum mencapai indikator keberhasilan. Hal ini perlu menjadi bahan refleksi agar terjadi perbaikan pada siklus II.

4. Refleksi

Tujuan dilakukan refleksi adalah untuk memperbaiki proses pembelajaran pada siklus berikutnya, dimana guru mengemukakan kekurangan-kekurangan yang terjadi pada siklus sebelumnya. Berikut ini adalah hasil refleksi yang dilakukan oleh guru dan peneliti yaitu:

a. Persentase aktivitas belajar belum mencapai indikator keberhasilan. Hal ini disebabkan oleh kurangnya pelaksanaan proses pembelajaran yang dilakukan guru diantaranya adalah:

1) Guru tidak menjelaskan bahwa akan ada kelompok terbaik yang dinilai dari jumlah aktivitas yang dilakukan oleh masing-masing kelompok.

2) Guru tidak mengontrol siswa yang bertanya,menjawab, dan memberikan saran/tanggapan sehingga hanya dilakukan oleh siswa-siswa tertentu saja.

3) Guru tidak menegur siswa yang kurang memperhatikan dan kurang aktif dalam pembelajaran.

b. Alokasi waktu yang digunakan belum sesuai dengan RPP.

c. Proses pelaksanaan pembelajaran meskipun sudah mencapai indikator keberhasilan, namun masih terdapat kekurangan pelaksanaan yang berdampak pada akvititas dan hasil belajar siswa, diantaranya adalah:

1) Guru kurang menekankan penyampaian motivasi kepada siswa di kegiatan awal.

2) Sebelum membagikan leaflet guru tidak menjelaskan bagian halaman dan materi pada leaflet.

3) Guru tidak memberikan penghargaan kepada kelompok terbaik.

\section{Siklus II}

1. Perencanaan

Perencanaan siklus I dilakukan dengan menyiapkan perangkat pembelajaran dan instrument penelitian seperti pada siklus I. Namun pada siklus II ditambah dengan perbaikan-perbaikan yang harus dilakukan berdasarkan hasil refleksi pada siklus I.

2. Pelaksanaan

Tahap ini dilakukan proses pembelajaran menggunakan model kooperatif TTW. Proses pembelajaran dilakukan oleh peneliti, sedangkan guru mata pelajaran bertindak sebagai observer untuk pelaksanaan proses pembelajaran. Langkahlangkah pembelajaran sama seperti pelaksanaan pada siklus I, dan ditambah perbaikan-perbaikan berdasarkan hasil refleksi siklus I.

3. Observasi

Hasil dari observasi menunjukkan bahwa proses pembelajaran meningkat dengan kategori baik sebesar $100 \%$, artinya terjadi peningkatan sebesar 5,4\%. Aktivitas belajar telah mencapai indikator keberhasilan yaitu sebesar 75,76\%. Persentase jumlah siswa yang aktif meningkat menjadi 87,88\%.

4. Refleksi

Selain untuk memperbaiki proses pembelajaran berikutnya, tujuan dilakukannya refleksi adalah untuk membahas hasil observasi. Hasil refleksi yang dilakukan oleh guru dan peneliti adalah sebagai berikut:

a. Pengalokasian waktu pelaksanaan proses pembelajaran sudah cukup baik walaupun secara keseluruhan lebih 2 menit dari alokasi tahap perencanaan.

b. Guru telah melaksanakan tahap pembelajaran sesuai dengan RPP dengan baik.

c. Siswa sudah lebih aktif dalam pembelajaran karena guru memotivasi untuk selalu aktif dalam pembelajaran.

d. Pada saat presentasi, siswa yang lain aktif memperhatikan dan mengajukan pertanyaan kepada kelompok yang presentasi.

e. Pemahaman siswa terhadap materi sudah baik dibuktikan dengan adanya peningkatan ketuntasan hasil belajar dan telah mencapai indikator keberhasilan.

Berdasarkan refleksi pada siklus II diketahui bahwa proses pembelajaran dengan model 
kooperatif TTW sudah terlaksana dengan baik. Semua aktivitas dan hasil belajar telah mengalami peningkatan dan mencapai indikator keberhasilan sesuai dengan keinginan guru dan peneliti. Hasil belajar dan segala variabel penunjang akan meningkat jika kondisi dalam kelas sudah kondusif (Jamil, 2019; Krismawati, 2019; Rosari, 2019; Satria \& Kusumah, 2019; Walid, Putra, \& Asiyah, 2019). Guru dan peneliti memandang bahwa perlu tidak melanjutkan tindakan ke siklus berikutnya karena sudah mencapai indikator keberhasilan.

\section{KESIMPULAN}

Berdasarkan hasil penelitian dan pembahasan dapat disimpulkan bahwa model pembelajaran kooperatif TTW berbantuan leaflet dapat meningkatkan aktivitas dan hasil belajar siswa pada materi perubahan lingkungan di kelas X MIA 3 SMA Muhammadiyah 1 Pontianak.

Secara khusus, dari hasil penelitian yang telah dilaksanakan dapat disimpulkan bahwa:

Aktivitas belajar siswa pada materi perubahan lingkungan menggunakan pembelajaran kooperatif TTW di kelas X MIA 3 SMA Muhammadiyah 1 Pontianak pada siklus I siswa yang tergolong aktif sebesar 60,61\% dan mengalami peningkatan pada siklus II menjadi $75,76 \%$.

Hasil belajar siswa pada materi sistem perubahan lingkungan menggunakan pembelajaran kooperatif TTW berbantuan leaflet di kelas X MIA 3 SMA Muhammadiyah 1 Pontianak pada siklus I siswa yang telah mencapai ketuntasan belajar sebesar 75,76\% dan mengalami meningkat pada siklus II menjadi $87,88 \%$.

Proses pembelajaran pada materi perubahan lingkungan menggunakan pembelajaran kooperatif TTW berbantuan leaflet di kelas X MIA 3 SMA Muhammadiyah 1 Pontianak pada siklus I terlaksana baik dengan persentase keterlaksanaan 94,44\% sedangkan pada siklus II mengalami peningkatan dengan persentase $100 \%$. Hal ini menunjukkan adanya peningkatan dalam keterlaksanaan pembelajaran. Saran

Sebaiknya pada siklus I dan siklus II guru selalu memperhatikan alokasi waktu yang telah ditentukan di RPP agar semua kegiatan pembelajaran dapat dilakukan secara maksimal.

Guru meningkatkan kemampuan untuk mengatasi kelemahan model kooperatif TTW diantaranya memonitoring partisipasi siswa, dan memutuskan kapan dan bagaimana mendorong setiap siswa untuk berpartisipasi.

Sebaiknya peneliti merekan video saat penelitian agar dapat memperoleh informasi lebih detail mengenai proses pembelajaran aktivitas belajar siswa.

\section{DAFTAR PUSTAKA}

Ameliawati, D. (2013). Pengaruh Penggunaan Bahan Ajar Leaflet Terhadap Aktivitas Dan Hasil Belajar Siswa. Jurnal Profesi Kependidikan. 3 (1): 92-102

Arikunto, S. (2013). Prosedur Penelitian : Suatu Pendekatan Praktik. Jakarta: Rineka Cipta

Arsyad, A. (2015). Media Pembelajaran. Jakarta : Raja Grafindo Persada

Asyhar, R. (2015). Kreatif Mengembangkan Media Pembelajaran. Yogyakarta: Buku Beta

Hamdayana, J. (2015). Model Pembelajaran Kreatif dan Berkarakter. Jakarta: Gelora Aksara

Hermawan, D. (2013). MeningkatkanAktivitas Dan HasilBelajar Siswa Menggunakan Bahan Leaflet Melalui Tipe Stad. Jurnal Pendidikan. 3 (1): 12-19

Hisyam, Z. (2008). Strategi Pembelajaran Aktif: Yogyakarta : Insan Mandiri

Huda, M. (2016). Cooperative Learning: Metode, Teknik, Struktur, dan Model Penerapan. Yogyakarta: Pustaka Pelajar

Jamil, M. M. (2019). Optimalisasi Model ARCS Dalam Pembelajaran Saintifik Untuk Meningkatkan Motivasi Belajar Peserta Didik Pada Peminatan Mata Pelajaran Geografi Di Kelas Matematika Ilmu Alam. IJIS Edu: Indonesian Journal of Integrated Science Education, 1(1), 7-24. https://doi.org/10.29300/ijisedu.v1i1.14 01 
Kusuma, W \& Dwitagama. (2010). Mengenal Penelitian Tindakan Kelas Edisi Kedua. Jakarta: Indeks

Krismawati, N. U. (2019). Pengembangan Bahan Ajar Penulisan Sejarah Berbasis Model Project-Based Learning. Indonesian Journal of Social Science Education (IJSSE), 1(2), 156170.

https://doi.org/10.29300/IJSSE.V1I2.19 05

Mahmud. (2011). Metode Penelitian Pendidikan. Bandung: Pustaka Setia.

Masitoh, D. (2017). Peningkatan Keaktifan dan Hasil Belajar IPA Konsep Sistem Gerak pada Manusia melalui Strategi Think Talk Write. Jurnal Profesi Keguruan. 3 (1): 92-104

Murni. (2010). Panduan Penulisan Baban Ajar. Jakarta: Rajawali Press

Nuraini, F \& Raudhatul, Fadhilah. (2018). Hubungan Antara Aktivitas Belajar Siswa dan Hasil Belajar pada Mata Pelajaran Kimia Kelas X Sma Negeri 5 Pontianak. Ar-Razi Jumal Ilmiah. 6 (2): 27-32

Rosari, I. (2019). Pengaruh Strategi Pembelajaran dan Gaya Kognitif Spasial Terhadap Hasil Belajar Ikatan Kimia SMA. IJIS Edu: Indonesian Journal of Integrated Science Education, 1(2). https://doi.org/10.29300/ijisedu.v1i2.19 66

Ryanti, W. (2016). Penerapan Model Pembelajaran TTW Untuk Meningkatkan Aktivitas Dan Hasil Belajar Siswa Kelas V Pada Mata Pelajaran Ips Sd Negeri 9 Metro Timur Tahun Pelajaran 2015/2016. L Education. 5 (2): 33-38

Sanjaya, W. (2014). Strategi Pembelajaran. Jakarta: kencana
Satria, I., \& Kusumah, R. G. T. (2019). Analisis Keterkaitan Motivasi Dan Apersepsi Terhadap Hasil Belajar IPS. Indonesian Journal of Social Science Education (IJSSE), 1(1), 114-123. https://doi.org/10.29300/IJSSE.V1I1.25 87

Septiani, E, Tri Jalmo, \& Berti Yolida. (2014). Penggunaan Bahan Ajar Leaflet Terhadap Hasil Belajar Siswa. Jurnal Bioterdidik: Wahana Ekspresi Ilmiah. 2 (4): 92-101

Setyono, B. (2005). Media Pendidikan. Sukoharjo: FKIP Press

Sibuea, M (2017). Implementasi Model Pembelajaran Kooperatif Tipe Think Talk Write sebagai Upaya Meningatkan Hasil Belajar Siswa. Mes (Journal of Mathematics Education and Science). 2 (2): 42-48

Sudarmiyati, W. (2016). Peningkatan Hasil Belajar IPA melalui Model Pembelajaran Kooperatif Tipe Think Talk Write pada Siswa Kelas VIII 5.JPF Jurnal Pendidikan Fisika Universitas Mubammadiyah Metro. 4 (2): 86-96.

Sudjana, N. (2010). Metode Statistika Edisi ke-6. Bandung: Tarsito.

Suprijono, A. (2014). Cooperative Learning: Teori dan Aplikasi PAIKEM. Yogyakarta : Pustaka Pelajar.

Suyatno. (2009). Menjelajah Pembelajaran Inovatif. Sidoarjo: Masmedia Buana.

Uno, H.B., Lamatenggo,N., Koni, S.MA. (2014). Menjadi Peneliti PTK yang Profesional. Jakarta : PT Bumi Aksara.

Walid, A., Putra, E. P., \& Asiyah. (2019). Pembelajaran Biologi Menggunakan 
Problem Solving Disertai Diagram Tree

Untuk Memberdayakan Kemampuan

Berpikir Logis Dan Kemampuan

Menafsirkan Siswa. IJIS Edu: Indonesian Journal of Integrated Science Education, 1(1), 16.

https://doi.org/10.29300/ijisedu.v1i1.13 98 